\title{
The Relationship between Seed Size and Seed Quality in UNPAD New Seed Collection of Sweet Corn Lines after Storage
}

\author{
Muhamad Kadapi \\ Department of Crop Production \\ Faculty of Agriculture, Universitas Padjadjaran \\ Sumedang, Indonesia \\ kadapi@unpad.ac.id \\ Agus Wahyudin \\ Department of Crop Production \\ Faculty of Agriculture, Universitas Padjadjaran \\ Sumedang, Indonesia \\ agus.wahyudin@unpad.ac.id
}

\author{
Anne Nuraini \\ Department of Crop Production \\ Faculty of Agriculture, Universitas Padjadjaran \\ Sumedang, Indonesia \\ anne.nuraini@unpad.ac.id \\ Setiyo Anita Lestari \\ Department of Crop Production \\ Faculty of Agriculture, Universitas Padjadjaran \\ Sumedang, Indonesia \\ anitasetiyo.sa@gmail.com
}

\begin{abstract}
Seed size before storage can affect the performance of the seed after storage. Seed size correlates to energy reserves, and therefore an evaluation of the relationship between seed size and seed quality is needed. This paper discusses variations in the seed sizes of sixteen UNPAD sweet corn lines to determine the relationship between seed size and seed quality. The sweet corn lines used in this study were classified into two groups by seed mass (weight). Seeds classified as small averaged between 8.0-10.6 g per 100 seeds in mass, and heavy seeds averaged between $11.5-13.7 \mathrm{~g}$ per 100 seeds. The results showed that seed moisture content and germination rate were significantly correlated to seed size, and there was a slight positive correlation between the seed germination rate and seed weight. We conclude that heavy seeds were of better quality than small seeds.
\end{abstract}

Keywords-corn, equilibrium moisture content, inbred, longevity

\section{INTRODUCTION}

Sweet corn (Zea mays L. var. saccharata) is one of the vegetables most favoured by Indonesians. Unfortunately, sweet corn productivity in Indonesia between 2010 and 2015 was only 4.81 tons/ha, even though research indicates potential yields of up to 14-15 tons/ha [1]. In many crops, one of the major contributors to low yield is the use of low quality seed, as reported by [2] about wheat, [3] about peanuts, and [4] about maize. Many factors can cause seed quality to decrease, a phenomenon called "seed deterioration". One of these factors is storage duration [5], [6]. Seed quality can be assessed by measuring physical and physiological characteristics [7], [8], [9]. Munamava [10] reported that the seed quality of inbred lines is an important quality indicator for seed breeders because of the variations among seed lines. The physical quality of seed is evaluated by observing variations in the size, weight, and shape of individual seeds. Physiological quality measures viability and seed vigor [11]. El-Abady [4] reported that round maize seeds exhibit lower seedling performance than flat ones. [12], [13] reported that heavier seeds demonstrate better germination rates, seedling vigor, and sprouting capability, and also offer better economic yields than small seeds. Several studies have reported similar results and suggest that heavy seed conferred an advantage during storage and retains excellent germination characteristics over long storage periods [14], [15]. Also, several researchers have observed that seed of different genotypes behaves differently during storage [16 - 18].

Research on variations within UNPAD maize lines has been conducted since 2005, using quality protein maize (QPM) and downy mildew resistance lines as breeding materials [19]. However, little research has been done on the study of seed quality. Therefore, the objectives of this study were to characterize the quality of 16 seed lines selected from the new UNPAD sweet corn collection and to determine the relationship between physical and physiological seed qualities among lines, with the goal of optimizing these lines for future use as breeding materials.

\section{METHODS}

This experiment was conducted in the Plant Breeding and Seed Technology Laboratory of Faculty of Agriculture Universitas Padjadjaran (UNPAD) from July 2017 to January 2018. The seed used in this experiment was selected from 16 inbred lines of UNPAD sweet corn seed generated using several breeding materials and methods (Table 2). The seed of 16 lines was arranged by weight per 100 seeds and examined by PCA (Principal Component Analysis). The seeds were stored in porous fabric packages grouped into ventilated boxes. Temperature and relative humidity measurements were collected from digital thermohygrometers every day during storage period (Table 1).

Table 1. Temperature and relative humidity during seed storage

\begin{tabular}{lcc}
\hline \multirow{2}{*}{ Month } & \multicolumn{2}{c}{ Observation } \\
\cline { 2 - 3 } & $\begin{array}{c}\text { Temperature }\left({ }^{\circ} \mathrm{C}\right) \\
\text { (Standard error) }\end{array}$ & $\begin{array}{c}\text { Relative humidity (\%) } \\
\text { (Standard error) }\end{array}$ \\
\hline $1^{\text {st }}$ & $25.7(0.81)$ & $64.2(1.86)$ \\
$2^{\text {nd }}$ & $25.1(0.77)$ & $61.4(1.88)$ \\
$3^{\text {rd }}$ & $26.3(0.82)$ & $56.0(2.57)$ \\
$4^{\text {th }}$ & $24.8(0.65)$ & $64.0(1.12)$ \\
Mean & 25.0 & 63.7
\end{tabular}


The experiment used a simple completely randomized design and consisted of 16 treatments with two replications. The quality parameters measured in this study were physical (moisture content of seeds, and seed weight), and physiological (seed germination, and synchrony germination of seeds). All parameters were measured before and after the storage periods ( 2 and 4 months). The data obtained were analyzed using regression-correlation tests run in SPSS 24 software.

\section{A. Seed Moisture Content}

Seed moisture content was measured using the ISTA oven method. We exposed samples to a temperature of $130^{\circ} \mathrm{C}$ for 36 hours, and then calculated the percentage of seed moisture content using the following formula [20].

$$
\begin{aligned}
& \text { MC }(\%)=\frac{W 1-W 2}{W 1} \times 100 \% \\
& \text { Key: } \\
& M C=\text { Moisture content } \\
& \text { W1 = Seed weight before oven (wet) } \\
& \text { W2 = Seed weight after oven (dry) }
\end{aligned}
$$

\section{B. Seed Germination}

The seed germination tests were conducted using paper roll in a solar germinator at room temperature, and counted germinated seeds at four and seven days [21 - 23]. The seed germination percentage was calculated using the formula:

$$
\mathrm{G}(\%)=\frac{\mathrm{N} 4+\mathrm{N} 5+\mathrm{N} 6+\mathrm{N} 7}{\text { Number of added seed }} \times 100 \%
$$

Key:

$\mathrm{G}=$ Seed germination

N4 = Number of normal sprouts on 4th day

N5 $=$ Number of normal sprouts on 5th day

N6 $=$ Number of normal sprouts on 6th day

N7 = Number of normal sprouts on 7th day

\section{Synchrony of Seed Germination}

The synchrony of seed germination was calculated as a percentage of the seed that had germinated normally at four days [23].

\section{RESULTS AND DISCUSSION}

The seed lines were classified into two groups, small and large seeds (Table 2). Seed size classification was based on the weight of 100 seeds. Small seeds ranged between 8.0-10.6 g per 100 seeds and the heavy seeds ranged between 11.5 13.7 grams per 100 seeds. All the maize seed used in this study was the "dent" shape type.

The seed moisture content percentage was not significantly correlated with seed mass before the 4-month storage period (Table 3 and Fig. 1). However, there was a strong and significant correlation between the seed moisture content and seed mass after 4 months of storage. This indicates that after 4 months, the heavy seed had maintained a lower water content than light seeds.
The germination percentage was insignificantly correlated with seed mass before the 4-month storage period (Table 3 and Fig. 2). However, there was a significant positive correlation between synchrony of germination rate and seed mass after 4 months of storage. The result suggested that synchrony of germination in maize is affected by seed mass.

Table 2. Quality of UNPAD sweet corn seed before storage

\begin{tabular}{ccccc}
\hline \multirow{2}{*}{ No } & \multicolumn{4}{c}{ Seed Quality Parameters } \\
\cline { 2 - 5 } & Lines & 100 Seed Weight $($ g) & Seed size & Seed type \\
\hline 1 & P5xP3(x)(5) & 8,00 & Small & dent \\
2 & P1(x)(5) & 8,75 & Small & dent \\
3 & P5xP1(x)(2) & 9,54 & Small & dent \\
4 & P5xP2(x)(3) & 9,73 & Small & dent \\
5 & P7xP4(x)(7) & 10,58 & Small & dent \\
6 & P6xP5(x)(4) & 11,47 & Large & dent \\
7 & P7xP2(x)(4) & 11,61 & Large & dent \\
8 & P6xP5(x)(8) & 12,22 & Large & dent \\
9 & P5xP1(x)(3) & 12,24 & Large & dent \\
10 & P6xP5(x)(16) & 12,26 & Large & dent \\
11 & P3xP2(x)(5) & 12,36 & Large & dent \\
12 & P1(x)(4) & 12,47 & Large & dent \\
13 & P1(x)(6) & 12,64 & Large & dent \\
14 & P7xP3(x)(2) & 12,71 & Large & dent \\
15 & P3xP2(x)(3) & 13,49 & Large & dent \\
16 & P7xP2(x)(5) & 13,69 & Large & dent \\
\hline & & & & \\
\hline
\end{tabular}

The synchrony of seed germination rates in heavy seed was better than that of small seeds after storage. Germination synchrony did not significantly correlate with the weight of 100 seeds (Table 3 and Fig. 3). However, synchrony of germination rates was moderately positively correlated with seed mass in (Fig. 3). This result suggests that a heavy seed had good longevity.

Table 3. Coefficient of correlation between seed mass and seed quality parameters

\begin{tabular}{ccccc}
\hline Times & $\begin{array}{c}\text { Seed } \\
\text { moisture } \\
\text { content }\end{array}$ & $\begin{array}{c}\text { Seed } \\
\text { Germination }\end{array}$ & $\begin{array}{c}\text { Synchrony } \\
\text { of Seed } \\
\text { Germination }\end{array}$ \\
\cline { 2 - 5 } seed & Before storage & 0.169 & -0.068 & -0.266 \\
mass & 2 month storage & 0.080 & 0,263 & -0.209 \\
& 4 month storage & $-0.744^{* *}$ & $0.542^{*}$ & 0.209 \\
\hline & Note: ** $=$ correlation is significant at the 0.01 level (2 tailed) and s $^{*}$ correlation is \\
& & & significant at the 0.05 level (2 tailed)
\end{tabular}

In this study, the correlations between the seed mass and several physical and physiological traits were evaluated as measures of seed quality. 


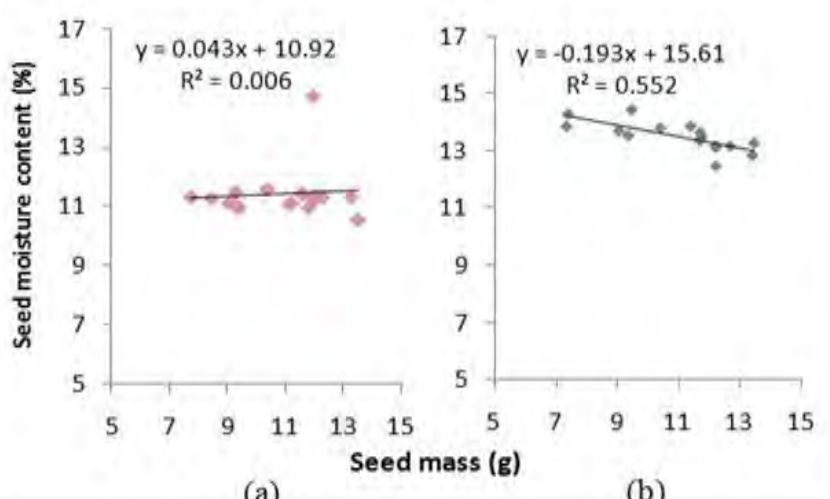

(a)

(b)

Figure 1. Linier regression and correlation between seed mass and seed moisture content, (a) after 2 months storage, (b) after 4 months storage.

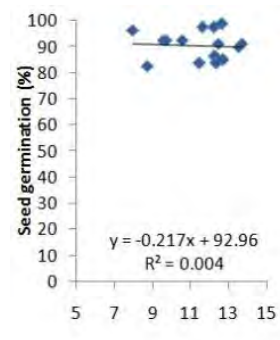

(a)

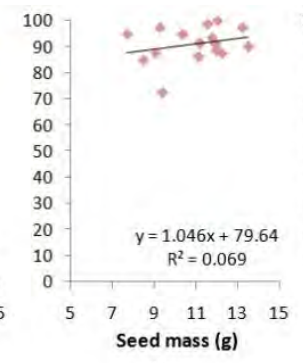

(b)

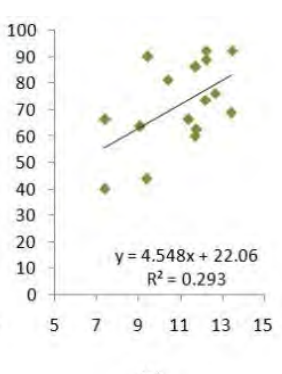

(c)
Figure 2. Linier regression and correlation between seed mass and seed germination, (a) before storage, (b) after 2 months storage, (c) after 4 months storage.

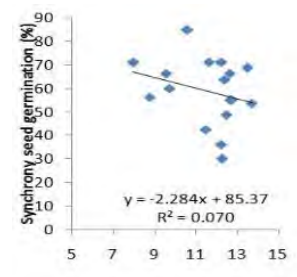

(a)

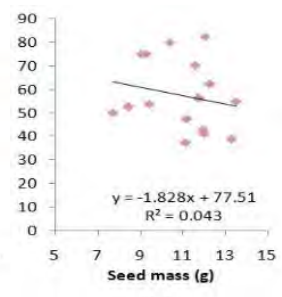

(b)

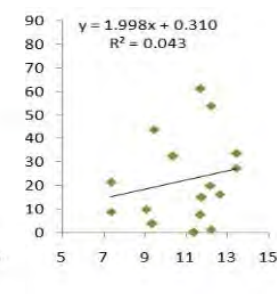

(c)
Figure 3. Linier regression and correlation between seed mass and synchrony of seed germination, after storage (a) before storage, (b) after 2 months storage, (c) after 4 months storage.

Our study agrees with [24] which suggested that small maize seeds could absorb higher water vapor than heavy seeds because they have proportionally larger surface areas, permitting greater absorption. Furthermore, corn seeds with high protein content could absorb water vapor with highest capacity [25]. Seed germination rate measures the ability of seeds to grow into normal plants under optimum conditions [26]. Many things can decrease the germination rate of seed stored in an open storage system. The two most important factors revealed by our study were the temperature and relative humidity in the storage room [27], [28].

We used open storage system to identify which lines exhibit the best longevity. Our research revealed that the lines with heavy average seed sizes have higher germination rates than lines with smaller averages. Smaller seeds germinated more slowly and demonstrated lower germination percentages than heavier seeds, because the scutellum of a heavy seed has more stored energy than light seed as agreement in many crops, in field corn [29], in wheat [30] and in Artocorpus species [13]. The different amounts of food reserves in seeds and different embryo sizes affect their germination rates.

Synchrony of germination is one of the vigor parameters to quantify seed longevity [31], [32]. In our study, we found insignificant correlations between seed mass and synchrony of seed germination. However, the value of $R$-squared showed a positive correlation between them (0.04). It indicated that the heavy seeds had a higher degree of seed germination synchrony than small seeds. Vigor always decreased faster than viability [33]. We assumed that all seed lines would deteriorate over 4 months of storage. The increasingly size of seed has high value of seed germination as mention above due to energy source in heavy seed higher than small seed. Even though, the energy in heavy seed was not enough to maintain the level of synchronization of seed germinate after 4 month storage. This result agrees with results reported in several previous studies [34], [35].

The open storage method affected all of the parameters measured in this study. During the 4 months of storage, we collected room temperature and relative humidity data. According to the data, seed moisture content fluctuated with room temperature and relative humidity (Table 1). This phenomenon is called "equilibrium moisture content (EMC)" [36].

McDonald [36] suggested that seed moisture content and the equilibrium seed moisture content affect seed performance and are important factors impacting seed longevity. We found significant correlations between seed mass and the other parameters measured in this study because of the EMC affect with reference to seed mass. We suggest that the seed mass or weight of seed should be considered when selecting lines to use as breeding .material to develop new varieties for the UNPAD maize collection.

The low germination rate and the synchrony of germination in small sweet corn seeds was due to the higher water content of the seeds. Small sweet corn seeds after storage had higher moisture content than heavier seeds (Fig. 1). Seed with high moisture content has an increased rate of respiration, which causes protein hydrolysis, depleting the food reserve in the seed [37]. The rule of thumb is that every $1 \%$ increase in seed moisture content and $5^{\circ} \mathrm{C}$ increase in storage temperature would decrease halves the life of the seed [38]. Our findings support earlier reports that seeds with high water content deteriorate more quickly and have lower germination rates [39], [40].

\section{CONCLUSION}

Our research indicates that heavy seeds perform better than small seeds after storage. The weight per 100 seeds, germination capability and synchrony of seed germination were the important traits and may useful for future breeding program.

\section{ACKNOWLEDGMENT}

We are grateful to Dr. Dedi Ruswandi for provided the seeds. Thanks to Annisa, Debby, Niki, Rezeki, and Rofi for their help in the laboratory. 


\section{REFERENCES}

[1] Badan Pusat Statistik (BPS). "Data produktivitas jagung". 2016.

[2] A. Barnard, and F.J. Calitz. "The effect of poor seed and various levels of grading factors on germination, emergence and yield of wheat". South African Journal of Plant and Soil. Vol. 28. pp. 23-33. 2013.

[3] M. Sun, J.F. Spears, T.G. Isleib, D.L. Jordan, B. Penny, D. Johnson, and S. Copeland. "Effect of production environment on seed quality of normal and high-oleate heavy seeded virginia-type peanut (Arachis hypogaea L.)". Peanut Science. Vol. 41. pp. 90-99. 2014.

[4] M.I. El-Abady. "Influence of maize seed size/shape, planted at different depths and temperature on seed emergence and seedling vigor". Research journal of Seed Science. Vol. 8, pp. 1-11. 2015.

[5] H. Merouni, C. Branco, M. Almeida, and J. Pereira. "Effects of acorn storage duration and parental tree on emergence and physiological status of cork oak (Quercus suber L.) seedling". Annals for Forest Science. Vol. 58. pp. 543-554. 2001.

[6] A.S. Goggi, P. Caragea, L. Pollak, G. McAndrews, M. DeVries, and K. Montgomery. "Seed quality assurance in maize breeding program: test to explain variations in maize inbreds and populations". Agronomy Journal. Vol. 100. pp. 337-343. 2008.

[7] L.J. Silva, C.F.S. Dias, C.C. Milagres, and L.A.S. Dias. "Relationship between fruit maturation stage and physiological quality of physic nut (Jatropha curcas L.) seeds". Ciencia e Agrotecnologia, Lavras. Vol. 36, pp. 39-44. 2012.

[8] T. N. Moreano, A.L. Braccini, C. A. Scapim, J.B. Franca-Neto, F.C. Krzyzanowski, and O.J. Marques. "Physical and physiologica qualities of soybean seed as affected by processing and handling". Journal of Seed Science. Vol. 35. pp. 466-477. 2013.

[9] M. Shibata, C.M.M. Coelho, C.G. Araldy, N. Adan, and N. Peroni. "Physiological and physical quality of local Araucaria angustifolia seed variety". Acta Scientiarum Agronomy. Vol. 38. pp. 249-256. 2016.

[10] M.R. Munamava, A.S. Goggi, and L. Pollak. "Seed quality of maize inbred lines with different composition and genetic backgrounds". Crop Science Society of America. Vol. 44. pp. 542-548. 2004.

[11] Illipronti Jr, R.A., Langerak, and W.J.M. Lommen. "Variation in and relation between physical and physiological seed attributes within soyben seed lot”. Seed Science and Technology. Vol. 5. pp. 215-231. 1997.

[12] M. R. Enayatgholizadeh, A. M. Bakhshandeh, M. D. Shoar, M. H. Ghaineh, K. H. A. Saeid, and M. Sharafizadeh. "Effect of source and seed size on yield component of corn S.C704 in Khuzestan". African Journal of Biotechnology. Vol. 11. pp. 2938-2944. 2012.

[13] M.L. Khan. "Effect of seed mass on seedling success in Artocarpus heterophyllus L., a tropical tree species of north-east India". Acta Oecologica International Journal of Ecology. Vol. 25. pp. 103-110. 2003.

[14] M.A. Clor, T.A. Al-Ani, and F. Charchafchy. "Germinability and seedling vigor of Haloxylon salicornicumi as affected by storage and seed size". Journal of Range Management. Vol. 29. pp. 60-62. 1976.

[15] P.G. Kennedy, N.J. Hausmann, E.H. Wenk, and T.E Dawson. "The importance of seed reserves for seedling performance: an integrated approach using morphological, physiological, and stable isotope techniques". Ecophysiology. Vol. 141. pp. 547-554. 2004

[16] P. Krishnan, and A. V. S. Rao. "Effects of genotypes and environment on seed yield and quality of rice". The Journal of Agricultural Science. Vol. 143. pp. 283-292. 2005

[17] J. Mrda, J. Crnobarac, N. Dusanic, S. Jocic, and V. Miklic. "Germination energy as a parameter of seed quality in different sunflower genotypes”. Genetika. Vol. 43. pp. 427-436. 2011.

[18] H.M. Bortey, A.O. Sadia, and J.W. Asibuo. "Influence of seed storage techniques on germinability and storability of cowpea (Vigna unguiculata (L.) Walp)". Journal of Agricultural Science. Vol. 8. pp.241-248. 2016.

[19] D. Ruswandi, N Wicaksana, M.B. Pabendon, M. Azrai, M. Rachmadi, A. Ismail, N. Carsono, F. Damayanti, and F. Kasim. "Molecular characterization of quality protein maize and downy mildew resistance line based on simple sequence repeats (SSRs) marker". Jurnal Pemuliaan Indonesia, Zuriat.Vol.16. pp. 2005
[20] ISTA. International Rules for Seed Testing. The International Seed Testing Association. Bassersdorf, Switzerland. 2008.

[21] ISTA. International Rules for Seed Testing. The International Seed Testing Association. Bassersdorf, Switzerland. 2003.

[22] A.S.R. Pinto, G.A. Freitas, N.J.M. Goncalves, H.F.F. Ramos, and I.T. Silva. "Test germination of corn seeds in different environtments". Brazilian Journal of Applied Technology for Agricultural Science, Guarapuava. Vol. 5. pp. 7-26. 2012.

[23] L. Sutopo. Teknologi Benih. Jakarta: PT Raja Grafindo Persada. 2010.

[24] T. J. Afolabi. "Modeling the water absorption characteristics of different maize (Zea mays L.) types during soaking". Journal Chemical and Process Engineering Research. Vol. 25. pp.53-66. 2014.

[25] F.N. Nweke. "Rate of water absorption andproximate analysis of different varieties of maize cultivated in Ikwo local government area of Ebony State, Nigeria”. African Journal of Biotechnology. 2010. Vol .9. pp.8913-8917.

[26] L.O. Copeland, and M.B. Mcdonald. "Principles of Seed Science and Technology". New York: Springer Science+Business Media, LLC. 2001.

[27] V. Goyender, T.A.S. Aveling, and Q. Kritzinger. "The effect of traditional storage methods on germination and vigor of maize (Zea mays L.) from northern KwaZulu-Natal and southern Mozambique". South African Journal of Botany. Vol. 74. pp. 190-196. 2008.

[28] B.K. Pradhan, and H.K. Badola. "Effect of storage condition and storage periods on seed germination in eleven populations of Swertia chirayota: a critically endangered medical herb in Himalaya". Scientific World Journal. Vol. 2012. pp. 1-9. 2011.

[29] C.S. Yusuf, N. Makete, and R. Jacob. "Effect of seed size on germination and early germination of maize (Zea mays)". International Journal of Scientific and Research Publication. Vol. 4. pp. 1-3. 2014.

[30] M.M. Nik, M. Babaeian, and A. Tavassoli. "Effect of seed size and genotype on germination characteristic and seed nutrient content of wheat". Scientific Research and Essays. Vol. 6. pp. 2019-2025. 2011.

[31] S. Sadjad. "Dari Benih Kepada Benih". Jakarta: PT. Gramedia Widiasarana Indonesia. 1993.

[32] J.N.S. Ribeiro, and C.S.B. Costa. "The effect of temperature regulation on seed germination of the tropical tree Myrsine parvifolia A. DC near its southern limit". South African Journal of Botany. Vol. 98. pp. 128133. 2015.

[33] L. Schmidt. "Tropical Forest Seed. Springer-Verlag Berlin Heidelberg". New York. 2007. pp. 406

[34] Y.H. Zhang, Y.P. Zhang, N. Liu, D. Su, Q.W. Xue, B.A. Stewart. "Effect of source-sink manipulation on accumulation of micronutrients and protein in wheat grains". Journal of Plant Nutrition and Soil Science. Vol. 175. pp. 622-629. 2012.

[35] M. Nadeem, A. Mollier, A. Vives, L.P. Homme, S. Niollet, and S. Pellerin. "Effect of phosphorus nutrition and grain position within maize cob on grain phosphorus accumulation". Spanish Journal of Agricultural Research. Vol. 12. pp. 486-491. 2014.

[36] M. McDonald. "Seed moiature and the equilibrium seed moisture content curve". Seed Technology. Vol. 29. pp. 7-18. 2007.

[37] S. Umar. "Pengaruh pemberian bahan organik terhadap daya simpan benih kedelai (Glycine max (L.) Merr)". Berita Biologi. Vol. 11. pp. 401-410. 2012.

[38] J.F. Harrington. "Biochemical basis of seed longevity". Seed Science Technology. Vol. 1 pp. 453-461. 1973.

[39] A. Tatipata. "Pengaruh kadar air awal, kemasan, dan lama simpan terhadap protein membrane dalam mitokondria benih kedelai”. Bul. Agron. Vol. 36. pp. 8-16. 2008.

[40] H. H. S. Abad, A. Hamidi, G. N. Mohammadi, and A. Moghaddam. "Effect of storage condition, initial seed moisture content and germination on soybean seed deterioration". Iran Journal of Seed Research. Vol. 2. pp. 29-45. 2016. 